\title{
PENGEMBANGAN MULTIMEDIA SIMULASI INTERAKTIF STRUKTUR BUMI DAN BENCANANYA
}

\author{
Ricca Novita Sari* ${ }^{*}$ I Dewa Putu Nyeneng, Ismu Wahyudi \\ FKIP Universitas Lampung, Jln. Prof. Dr. Soemantri Brojonegoro No. 1 \\ *email: ricca.07byyy@gmail.com
}

\begin{abstract}
Development of Interactive Multimedia Simulation of Thee Earth Structure and Disasters. The research aim to produce interactive multimedia simulation model for learning the Earth Structure and Disasters for 7th grade of Juior High School that were validated, attractive, easy, useful, and effective. This reseach used reseach and development design with effectiveness test method used Pretest and Posstest Group. The result from the evaluation the expert (content and design) showed that the developed product were in a good category and valid. Small group test to 27 students in 7-1 class in the SMPN 02 Bandar Lampung concluded that interactive multimedia simulation was very interesting, very simplify, very useful, and effective as a learning.
\end{abstract}

Keyword: earth structure and disasters, interactive multimedia, research and development, simulation model.

\begin{abstract}
Abstrak: Pengembangan Multimedia Simulasi Interaktif Struktur Bumi dan Bencananya. Penelitian ini bertujuan untuk menghasilkan multimedia interaktif model simulasi untuk pembelajaran Struktur Bumi dan Bencananya di Kelas VII SMP yang tervalidasi, menarik, mudah, bermanfaat, dan efektif. Penelitian ini menggunakan desain research and development dengan metode uji keefektifan Pretest and Posstest Group. Hasil dari evaluai ahli (materi dan desain) menunjukkan bahwa produk yang dikembangkan berada dalam kategori baik dan valid. Uji kelompok kecil terhadap 27 siswa kelas 7-1 di SMPN 02 Bandar Lampung menyimpulkan bahwa multimedia interaktif simulasi sangat menarik, sangat mudah, sangat bermanfaat, dan efektif sebagai pembelajaran.
\end{abstract}

Kata kunci: model simulasi, multimedia interaktif, penelitian pengembangan, struktur bumi dan bencananya.

\section{PENDAHULUAN}

Struktur Bumi dan Bencananya merupakan materi IPA yang konsepnya bersifat abstrak. Materi ini menjelaskan mengenai struktur dalam bumi, lapisan atmosfer, proses terjadinya gempa bumi, tsunami, dan gunung api. Materi ini tidak bisa dilihat secara langsung, sehingga siswa yang kurang memiliki kemampuan berpikir abstrak dan berimajinasi akan mengalami kesulitan dalam memahami materi. Salah satu cara untuk membantu siswa memahami materi ini yaitu dengan menggunakan suatu media pembelajaran yang mampu memodelkan suatu kejadian atau fenomena-fenomena kebumian secara lebih nyata dalam pembelajarannya. Tetapi kenyataannya masih banyak guru di sekolah yang membelajarkan materi ini tanpa menggunakan bantuan media tersebut, sehingga kemampuan 
berpikir abstrak dan berimajinasi siswa yang tidak sama menghambat siswa dalam memahami materi yang ada. Upaya untuk mengatasi masalah ini adalah dengan mengembangkan media pembelajaran berupa multimedia interaktif model simulasi yang mampu memperjelas materi, mampu mengatasi keterbatasan indera, ruang, dan waktu, serta mampu mensimulasikan berbagai fenomena-fenomena bencana kebumian seperti proses terjadinya gempa bumi, tsunami, dan gunung api secara lebih nyata.

Arsyad (2011: 25) menjelaskan bahwa multimedia interaktif mampu memenuhi semua manfaat praktis dari penggunaan media pembelajaran dalam proses belajar mengajar yaitu: (1) mampu memperjelas penyajian pesan dan informasi, (2) mampu meningkatkan dan mengarahkan perhatian anak sehingga menimbulkan motivasi belajar, interaksi yang lebih langsung antara siswa dan lingkungannya, dan kemungkinan siswa untuk belajar sendiri-sendiri sesuai dengan kemampuan minatnya, (3) mampu mengatasi keterbatasan indera, ruang, dan waktu, dan (4) multimedia mampu memberikan kesamaan pengalaman kepada siswa tentang peristiwa-peristiwa di lingkungan mereka, serta memungkinkan terjadinya interaksi langsung dengan guru, masyarakat, dan lingkungannya.

Berdasarkan hasil wawancara dan angket analisis kebutuhan pada guru dan siswa di SMPN 02 Bandar Lampung diketahui bahwa guru di sekolah jarang menggunakan media pembelajaran berbasis komputer, apalagi multimedia interaktif model simulasi. Dari empat guru hanya satu guru yang pernah menggunakan media pembelajaran berbasis komputer dalam pembelajarannya. Media yang biasa digunakan guru dalam pembelajaran biasanya hanya sebatas buku cetak, modul, lembar kerja siswa (LKS), alatalat peraga dan KIT IPA. Menurut siswa, guru lebih sering menggunakan metode konvensional seperti ceramah, menghafal, menulis, dan latihan soal dalam membelajarkan materi di kelas. Hasil angket analisis kebutuhan siswa menunjukkan bahwa total skor 14,29 dari skor maksimal 16 (kategori sangat diperlukan) dan presentase $89,31 \%$ dari jumlah total skor jawaban siswa menyatakan bahwa sangat perlu dikembangkan multimedia interaktif model simulasi untuk pembelajaran Struktur Bumi dan Bencananya di kelas VII SMP.

Penelitian-penelitian yang telah dilakukan sebelumnya menyatakan bahwa membelajarkan materi IPA menggunakan multimedia interaktif diketahui sangat efektif, yaitu mampu meningkatkan hasil belajar siswa serta mampu meningkatkan minat dan motivasi belajar siswa. Tiurma dan Retnawati (2014) dalam penelitiannya menyatakan bahwa pembelajaran menggunakan multimedia lebih efektif dibandingkan pembelajaran yang tidak menggunakan multimedia, karena dapat meningkatkan minat dan hasil belajar siswa. Selain itu, Sukiyasa, dkk. (2013) dalam penelitiannya juga menyatakan bahwa hasil belajar dan motivasi belajar siswa yang diajarkan dengan media animasi lebih tinggi dibandingkan dengan hasil belajar dan motivasi belajar siswa yang diajarkan dengan media powerpoint.

Mulimedia interakif dikatakan layak dan valid apabila telah melewati proses evaluasi oleh para ahli dan memenuhi beberapa aturan tertentu. Sebagai media pembelajaran terkini multimedia interaktif telah banyak dikembangkan dan beredar di masyarakat luas terutama melalui jalur internet. Meskipun begitu, multimedia 
interaktif yang beredar di internet tersebut belum tentu layak dan valid untuk digunakan dalam proses pembelajaran. Darmawan (2012: 32) menerangkan bahwa suatu pembelajaran dapat dikatakan menggunakan multimedia interkatif jika memiliki karakteristik sebagai berikut, yaitu: (1) content representation, (2) full color and high resolution, (3) melalui media elektronik, (4) tipe-tipe pembelajaran yang bervariasi, (5) terdapat respon pembelajaran dan penguatan, (6) mengembangkan prinsip self evaluation, dan (7) dapat digunakan secara klasikal maupun individual.

Melihat kegunaan multimedia interaktif sebagai media pembelajaran yang mampu membantu memudahkan siswa dalam memahami materi dalam pembelajaran di kelas, maka dilakukan penelitian pengembangan multimedia interaktif model simulasi materi Struktur Bumi dan Bencananya di kelas VII SMP.

Tujuan penelitian pengembangan ini adalah untuk menghasilkan multimedia interaktif model simulasi materi Struktur Bumi dan Bencananya yang tervalidasi, serta mengetahui kualitas kemenarikan, kemudahan, kemanfaatan, dan keefektifan dari multimedia interakif model simulasi yang dikembangkan.

\section{METODE PENELITIAN}

Metode yang digunakan dalam penelitian ini adalah research and development (R\&D). Pengembangan yang dilakukan adalah pembuatan multimedia interaktif model simulasi dengan mengguanakan bantuan program (software) Macromedia Flash Professional 8. Materi yang digunakan dalam pengembangan produk ini berasal dari materi IPA SMP Kelas VII semester genap yaitu tentang Struktur Bumi dan Bencanaya yang sesuai dengan Kurikulum 2013 Revisi. Subjek penelitian ini adalah siswa kelas 7-1 di SMP Negeri 02 Bandar Lampung. Pada penelitian ini siswa dijadikan sampel penelitian untuk memperoleh data mengenai kemenarikan, kemudahan, kemanfaatan, dan keefektifan dari multimedia interaktif model simulasi yang dikembangkan.

Prosedur penelitian pengembangan dilakukan menggunakan prosedur pengembangan media dan bahan ajar dari Warsita (2008: 225) yang telah dimodifikasi. Prosedur pengembangan produk ini terdiri dari tujuh tahapan, yaitu: 1) Analisis Kebutuhan, 2) Penulisan GBIM (Garis Besar Isi Media) dan Jabaran Materi (JM), 3) Penulisan Naskah atau storyboard, 4) Produksi, 5) Evaluasi Ahli, 6) Revisi, dan 7) Uji Coba Lapangan.

Pengembangan produk multimedia interaktif model simulasi diawali dengan melakukan analisis kebutuhan di SMP Negeri 02 Bandar Lampung. Selanjutnya dilakukan penulisan GBIM yang berisi tentang judul media, KI dan KD materi yang digunakan, sasaran media, peta konsep, flowchart, jenis penilaian, dan sumber buku acuan. Penjabaran materi dilakukan berdasarkan peta konsep. Langkah selanjutnya adalah penulisan naskah atau storyboard. Setelah storyboard selesai dibuat, tahapan selanjutnya adalah produksi. Proses produksi multimedia interaktif model simulasi dilakukan dengan menggabungkan teks, gambar, suara, animasi, simulasi, soal-soal interaktif yang dilengkapi dengan perekemaan nilai unuk setiap jawaban benar, dan tombol-tombol interaktif yang dibantu dengan program Macromedia Flash Professional 8. Produk yang selesai dibuat selanjutnya dievaluasi oleh ahli, yang terdiri dari uji ahli materi dan uji ahli desain media untuk mengetahui kevalidan dan 
kelayakan produk yang telah dikembangkan. Revisi atau perbaikan produk dilakukan pada bagian-bagian yang kurang tepat sesuai dengan kritik dan saran perbaikan yang diberikan. Untuk mengetahui kualitas kemenarikan, kemudahan, dan kemanfaatan, serta keefektifan produk yang dikembangkan, dilakukanlah uji coba lapangan ke sekolah yang terbagi menjadi dua uji, yaitu uji satu lawan satu yang dilakukan pada tiga orang siswa dan uji coba kelompok kecil yang dilakukan pada 27 siswa kelas 7-1 SMPN 02 Bandar Lampung.

Teknik pengumpulan data dalam penelitian ini dilakukan dengan empat macam cara, yaitu (1) wawancara: dilakukan pada analisis kebutuhan kepada guru; (2) angket: dilakukan pada analisis kebutuhan siswa, uji ahli materi dan desain, uji satu lawan satu, dan uji kemenarikan, kemudahan, dan kemanfaatan; (3) observasi sarana dan prasarana di sekolah; dan (4) tes khusus: dilakukan pada uji keefektifan produk yang menggunakan desain pengujian Pretest and Posttest Group.

Instrumen yang digunakan pada uji ahli materi dan desain, serta uji satu lawan satu adalah lembaran angket yang berupa daftar cek (check-list) yang berisi pertanyaan-pertanyaan beserta dua pilihan jawaban mutlak, yaitu "Ya" dan "Tidak". Revisi produk dilakukan pada konten pertanyaan yang diberi pilihan jawaban "Tidak" dan pada bagian khusus yang diberi kritik dan saran-saran perbaikan.

Instrumen yang digunakan dalam uji kemenarikan, kemudahan, dan kemanfaatan adalah berupa lembaran angket dengan skala penilaian (rating scale). Angket skala penilaian tersebut memiliki 4 pilihan jawaban yang sesuai dengan konten pertanyaan yang ada yaitu misalnya: "Sangat Menarik", "Menarik", "Kurang Menarik", dan
"Tidak Menarik". Masing-masing pilihan jawaban tersebut memiliki skor berbeda yang mengartikan tingkat kesesuaian produk yang dihasilkan bagi pengguna. Skor penilaian dari tiap pilihan jawaban ini dapat dilihat pada Tabel 1.

Instrumen yang digunakan dalam uji kemenarikan, kemudahan, dan kemanfaatan memiliki 4 pilihan jawaban, sehingga nilai dapat dicari dengan menggunakan rumus:

$$
\text { Nilai }=\frac{\text { Jumlah skor yang diperoleh }}{\text { Jumlah skor maksimal }} \times 4
$$

Hasil dari nilai yang telah diperoleh kemudian dicari rata-ratanya dan dikonversikan ke pernyataan penilaian untuk menentukan kualitas dan tingkat kemenarikan, kemudahan, dan kemanfaatan dari produk yang dihasilkan berdasarkan pendapat pengguna. Hasil konversi ini diperoleh dengan melakukan analisis data secara deskriptif terhadap skor penilaian yang diperoleh. Pengkonversian skor menjadi bentuk pernyataan penilaian dapat dilihat pada Tabel 2 .

Tabel 1. Penskoran Pilihan Jawaban

\begin{tabular}{llc}
\hline Pilihan & Pilihan & Skor \\
Jawaban & Jawaban & 4 \\
\hline Sangat menarik & Sangat baik & 3 \\
Menarik & Baik & 2 \\
Kurang menarik & Kurang baik & 1 \\
Tidak menarik & Tidak baik & (Suyanto dan Sartinem, 2009)
\end{tabular}

Tabel 2. Konversi Skor Menjadi Bentuk Pernyataan

\begin{tabular}{ccc}
\hline Skor & Rerata Skor & Klasifikasi \\
\hline 4 & $3,26-4,00$ & Sangat baik \\
3 & $2,51-3,25$ & Baik \\
2 & $1,76-2,50$ & Kurang Baik \\
1 & $1,01-1,75$ & Tidak Baik \\
\hline
\end{tabular}

(Suyanto dan Sartinem, 2009) 
Tabel 3. Kategori Nilai N-Gain menurut Hake

\begin{tabular}{cc}
\hline Rentang Nilai $\boldsymbol{N}$-Gain & Kategori \\
\hline$N$-Gain $>0,7$ & Tinggi \\
$0,3 \leq N$-Gain $\leq 0,7$ & Sedang \\
$N$-Gain $<0,3$ & Rendah \\
\hline & (Mahardika, dkk., 2012)
\end{tabular}

Instrumen yang digunakan dalam uji keefektifan produk adalah tes khusus berupa soal pilihan jamak yang terdiri dari dua jenis tes, yaitu pretest (diberikan sebelum siswa menggunakan produk) dan posttest (diberikan setelah siswa menggunakan produk). Peningkatan nilai pretest dan posttest dapat diketahui dengan menganalisis data menggunakan persamaan $N$-Gain (normalizeed gain):

$$
N-\text { Gain }=\frac{(\text { Skor Posttest }- \text { Skor Pretest })}{(\text { Skor Maks }- \text { Skor Pretest })}
$$

Produk yang dikembangkan efektif apabila peningkatan nilai pretest dan posttest atau skor $N$-Gain mencapai kategori sedang $(0,3 \leq N$ Gain $\leq 0,7)$ atau kategori tinggi $(N$ Gain > 0,7).

\section{HASIL PENELITIAN}

Hasil utama dari penelitian pengembangan yang dilakukan di
SMPN 02 Bandar Lampung adalah multimedia interaktif model simulasi materi Struktur Bumi dan Bencananya untuk siswa kelas VII SMP yang dikemas dalam bentuk compact disk (CD). Multimedia interaktif ini berisi materi beserta gambar dan animasinya, simulasi-simulasi proses terjadinya bencana, soal-soal interaktif yang dilengkapi dengan perekaman nilai untuk setiap jawaban benar, petunjuk penggunaan, profil penulis, serta tombol-tombol interaktif.

\section{Hasil Evaluasi Ahli}

Evaluasi ahli meliputi dua tahapan, yaitu uji ahli materi, dan uji ahli desain. Uji ahli materi dilakukan oleh dosen Pendidikan Fisika FKIP Universitas Lampung yang ahli dalam bidang materi pembelajaran fisika. Sedangkan uji ahli desain dilakukan oleh dosen Pendidikan Fisika FKIP Universitas Lampung yang ahli dalam bidang desain media pembelajaran atau teknologi pembelajaran.

Rangkuman hasil uji ahli materi dan uji ahli desain dapat dilihat pada Tabel 4 dan 5.

Tabel 4. Rangkuman Hasil Uji Ahli Materi

\begin{tabular}{|c|c|c|}
\hline $\begin{array}{c}\text { Aspek } \\
\text { Penilaian } \\
\text { (1) }\end{array}$ & $\begin{array}{c}\text { Saran } \\
\text { Perbaikan } \\
(2) \\
\end{array}$ & $\begin{array}{c}\text { Perbaikan } \\
\text { yang Dilakukan } \\
(3) \\
\end{array}$ \\
\hline \multirow[t]{2}{*}{$\begin{array}{l}\text { Kelayakan } \\
\text { isi }\end{array}$} & $\begin{array}{l}\text { Sub judul "Tindakan Mengurangi } \\
\text { Bencana" kurang tepat, sebaiknya } \\
\text { diganti. }\end{array}$ & $\begin{array}{l}\text { Mengganti sub judul "Tindakan } \\
\text { Mengurangi Bencana" dengan sub judul } \\
\text { "Tindakan Tanggap Bencana" }\end{array}$ \\
\hline & Dicek kembali standar isi untuk SMP & Mengecek kembali standar isi untuk SMP \\
\hline \multirow{3}{*}{$\begin{array}{l}\text { Kelayakan } \\
\text { penyajian }\end{array}$} & $\begin{array}{l}\text { Tombol navigasi terlalu banyak } \\
\text { sehingga sulit diidentifikasi dan dilihat }\end{array}$ & $\begin{array}{l}\text { Mengurangi tombol navigasi dan } \\
\text { memperjelas tombol }\end{array}$ \\
\hline & $\begin{array}{l}\text { Dikurangi dominasi tulisan yang } \\
\text { berwarna-warni }\end{array}$ & $\begin{array}{l}\text { Mengurangi dominasi tulisan yang } \\
\text { berwarna-warni }\end{array}$ \\
\hline & $\begin{array}{l}\text { Sajikan pertanyaan dalam bentuk } \\
\text { gambar pada soal interaktif }\end{array}$ & $\begin{array}{l}\text { Menambahkan pertanyaan dalam bentuk } \\
\text { gambar pada soal interaktif }\end{array}$ \\
\hline
\end{tabular}


(1)

(3)

Ketika menjawab soal pada soal interaktif,, siswa masih bisa memilih jawaban lagi sampai benar, sehingga memungkinkan siswa untuk menjawab dengan menebak.

Mengubah fungsi tombol pada soal interaktif sehingga siswa hanya bisa menjawab satu kali untuk tiap pertanyaan.

Tabel 5. Rangkuman Hasil Uji Ahli Desain

\begin{tabular}{|c|c|c|}
\hline $\begin{array}{c}\text { Aspek } \\
\text { Penilaian }\end{array}$ & $\begin{array}{c}\text { Saran } \\
\text { Perbaikan }\end{array}$ & $\begin{array}{c}\text { Perbaikan } \\
\text { yang dilakukan }\end{array}$ \\
\hline \multirow{2}{*}{$\begin{array}{l}\text { Kesesuaian } \\
\text { huruf/teks } \\
\text { dan gambar }\end{array}$} & $\begin{array}{l}\text { Asal sumber gambar belum semua } \\
\text { dituliskan. }\end{array}$ & $\begin{array}{l}\text { Menambahkan asal sumber gambar } \\
\text { pada bagian yang belum ada }\end{array}$ \\
\hline & $\begin{array}{l}\text { Persingkat tampilan teks yang terlalu } \\
\text { panjang }\end{array}$ & $\begin{array}{l}\text { Mempersingkat tampilan teks yang } \\
\text { terlalu panjang }\end{array}$ \\
\hline $\begin{array}{l}\text { Kesesuaian } \\
\text { warna }\end{array}$ & $\begin{array}{l}\text { Sesuaiakan warna pada beberapa slide } \\
\text { agar terlihat kontras antara satu dan } \\
\text { lainnya }\end{array}$ & $\begin{array}{l}\text { Menyesuaikan/merevisi beberapa } \\
\text { warna pada slide agar terlihat lebih } \\
\text { kontras }\end{array}$ \\
\hline \multirow{2}{*}{$\begin{array}{l}\text { Kesesuaian } \\
\text { audio dan } \\
\text { video atau } \\
\text { simulasi }\end{array}$} & $\begin{array}{l}\text { Perjelas suara/narasi di bagian } \\
\text { "Pendahuluan". }\end{array}$ & $\begin{array}{l}\text { Memperjelas suara/narasi di bagian } \\
\text { "Pendahuluan" }\end{array}$ \\
\hline & $\begin{array}{l}\text { Tambahkan efek suara pada simulasi- } \\
\text { simulasi yang ada }\end{array}$ & $\begin{array}{l}\text { Menambahkan efek-efek suara pada } \\
\text { simulasi-simulasi yang ada }\end{array}$ \\
\hline $\begin{array}{l}\text { Kesesuaian } \\
\text { tombol }\end{array}$ & $\begin{array}{l}\text { Banyak tombol yang perlu } \\
\text { disederhanakan, dihilangkan, dibuat } \\
\text { kontras atau diperjelas bahwa bagian } \\
\text { itu adalah } \\
\text { sebuah tombol }\end{array}$ & $\begin{array}{l}\text { Menyederhankan tombol dan } \\
\text { menghilangkan tombol yang tidak } \\
\text { perlu, serta memperjelas tombol }\end{array}$ \\
\hline $\begin{array}{l}\text { Kesesuaian } \\
\text { tata letak }\end{array}$ & $\begin{array}{l}\text { Perbaiki tata letak yang ada ruang } \\
\text { kosongnya atau hilangkan ruang } \\
\text { kosong yang tidak perlu, dan perbaiki } \\
\text { tata letak tombol }\end{array}$ & $\begin{array}{l}\text { Menghilangkan ruang kosong yang } \\
\text { tidak perlu dan memperbaiki tata letak } \\
\text { tombol }\end{array}$ \\
\hline $\begin{array}{l}\text { Kesesuaian, } \\
\text { kelengkapan } \\
\text { struktural } \\
\text { multimedia }\end{array}$ & $\begin{array}{l}\text { Terlalu banyak balon pada bagian } \\
\text { cover, sehingga tombol "MENU" tidak } \\
\text { terlihat jelas }\end{array}$ & $\begin{array}{l}\text { Mengurangi balon-balon pada bagian } \\
\text { cover dan memperjelas tombol } \\
\text { "MENU" }\end{array}$ \\
\hline
\end{tabular}

\section{Hasil Uji Coba Lapangan}

Uji coba lapangan dilakukan untuk mengetahui tingkat kemenarikan, kemudahan, dan kemanfaatan multimedia interaktif yang telah dikembangkan serta untuk mengetahui tingkat keefektifannya dalam pembelajaran. Uji coba lapangan dibagi menjadi dua, yaitu uji coba satu lawan satu dan uji coba kelompok kecil.

Uji satu lawan satu dilakukan dengan memberlakukan produk kepada tiga orang siswa secara mandiri menggunakan bantuan laptop atau komputer. Selanjutnya ketiga siswa tersebut diberikan instrumen uji satu lawan satu untuk melihat respon pengguna terhadap produk yang dikembangkan yang dilihat dari aspek kemenarikan, kemudahan, dan kemanfaatan produk. Berdasarkan rekapitulasi hasil instrumen uji satu lawan satu diketahui bahwa siswa pertama 92,59\% menjawab "Ya", siswa kedua 96,29\% menjawab "Ya", dan siswa ketiga 92,59\% menjawab "Ya". 
Uji coba kelompok kecil dilakukan dengan memberlakukan produk sebagai kompelen atau pelengkap dalam pembelajaran terhadap 27 siswa kelas 7-1 di SMP Negeri 02 Bandar Lampung yang digunakan secara klasikal, yaitu digunakan bersamasama atau berkelompok di dalam kelas dengan bantuan laptop/komputer dan LCD. Selanjutnya 27 siswa tersebut diberikan instrumen uji kemenarikan, kemudahan, dan kemanfaatan untuk mengetahui respon pengguna terhadap produk yang dikembangkan, serta instrumen uji keefektifan produk. Rangkuman hasil uji kemenarikan, kemudahan, dan kemanfaatan serta rangkuman hasil uji keefektifan produk berdasarkan skor $\mathrm{N}$-Gain dapat dilihat pada Tabel 6 dan Tabel 7.

Tabel 6. Rangkuman Hasil Uji Kemenarikan, Kemudahan, dan Kemanfaatan

\begin{tabular}{lcl}
\hline Jenis Uji & $\begin{array}{c}\text { Rata- } \\
\text { rata } \\
\text { Skor }\end{array}$ & \multicolumn{1}{c}{$\begin{array}{c}\text { Pernyataan } \\
\text { Kualitatif }\end{array}$} \\
\hline Kemenarikan & 3,58 & Sangat menarik \\
Kemudahan & 3,63 & Sangat mudah \\
Kemanfaatan & 3,61 & Sangat bermanfaat \\
\hline
\end{tabular}

Tabel 7. Rangkuman Hasil Uji Keefektifan Berdasarkan Skor N-Gain

\begin{tabular}{ccc}
\hline Parameter & Pretest & Posttest \\
\hline Nilai Terendah & 40 & 65 \\
Nilai Tetinggi & 85 & 100 \\
Rata-rata & 63,7 & 88,0 \\
Gain Terendah & \multicolumn{2}{c}{10} \\
Gain Tertinggi & \multicolumn{2}{c}{40} \\
Rata-rata Gain & \multicolumn{2}{c}{24,3} \\
Rata-rata $N$-Gain & \multicolumn{2}{c}{0,7} \\
Kategori & \multicolumn{2}{c}{ Sedang } \\
\hline
\end{tabular}

Produk yang dikembangkan efektif apabila peningkatan nilai pretest dan posttest atau nilai $N$-Gain mencapai kategori sedang $(0,3 \leq \mathrm{N}$ -
Gain $\leq 0,7)$ atau kategori tinggi $(\mathrm{N}-$ Gain >0,7).

\section{PEMBAHASAN}

Validasi multimedia interaktif model simulasi dilakukan dengan evaluasi ahli yang terdiri dari uji ahli materi dan uji ahli desain. Berdasarkan uji ahli materi dan uji ahli desain diperoleh hasil yaitu multimedia interaktif model simulasi yang dikembangkan dinyatakan baik dan valid serta layak untuk digunakan dalam pembelajaran dengan beberapa kritik dan saran-saran perbaikan yang harus dilakukan.

Kemenarikan, kemudahan, dan kemanfaatan multimedia interaktif yang dikembangkan diperoleh dari uji satu lawan satu dan uji coba kelompok kecil. Berdasarkan hasil angket uji satu lawan satu, didapatkan data bahwa siswa pertama 92,59\% menjawab "Ya", siswa kedua 96,29\% menjawab "Ya" dan siswa ketiga 92,59\% menjawab "Ya", sehingga dapat dinyatakan bahwa multimedia interaktif model simulasi menarik, mudah, dan bermanfaat. Selain itu, berdasarkan hasil angket uji kemenarikan, kemudahan, dan kemanfaatan produk pada kelompok kecil diperoleh data seperti terlihat pada Gambar 1.

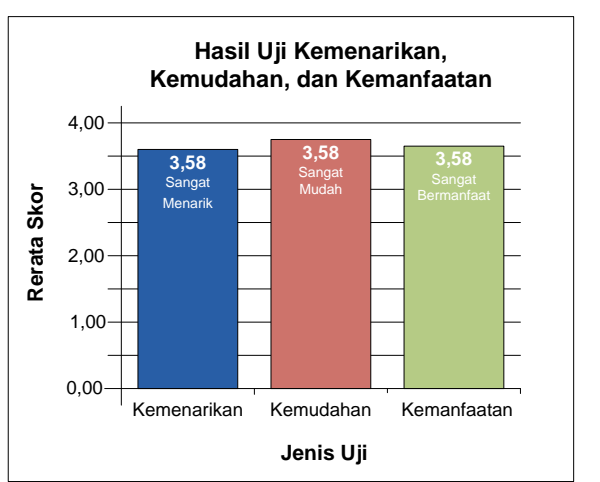
Gambar 1. Grafik Hasil Uji
Kemenarikan,
Kemudahan, dan
Kemanfaatan 
Berdasarkan grafik diperoleh skor rata-rata kemenarikan produk 3,58 dengan kategori sangat menarik, skor rata-rata kemudahan produk 3,63 dengan kategori sangat mudah, dan skor rata-rata kemanfaatan produk 3,61 dengan kategori sangat bermanfaat. sehingga dapat disimpulkan bahwa multimedia inter-aktif model simulasi yang dikembang-kan telah valid dengan kualitas sangat menarik, sangat mudah, dan sangat bermanfaat.

Kemenarikan multimedia interaktif model simulasi dapat dilihat dari segi tampilan slide-nya yang sangat menarik dan mencolok mata, seperti penggunaan warna-warna cerah, penggunaan jenis dan ukuran teks yang bervariasi, gambar-gambar, animasianimasi yang unik, serta simulasi yang sederhana dan menarik. Kemenarikan tampilan slide multimedia interaktif ini dapat dilihat pada Gambar 2.
Kemudahan multimedia interaktif model simulasi terletak pada segi penggunaanya yang mudah dan sederhana dengan bantuan tomboltombol interaktif yang telah disediakan. Tombol-tombol interaktif ini memungkinkan pengguna untuk langsung menuju slide yang diinginkan ketika tombol diklik, seperti pada slide peta konsep, dimana setiap bagian panelnya merupakan sebuah tombol interaktif sehingga dapat diklik secara langsung untuk menuju ke materi yang diinginkan. Selain itu multimedia interaktif model simulasi ini juga dilengkapi dengan petunjuk penggunaan sehingga pengguna tidak akan kebingungan dengan fungsi masingmasing tombol interaktifnya. Contoh tombol-tombol materi pada peta konsep dapat dilihat pada Gambar 3.
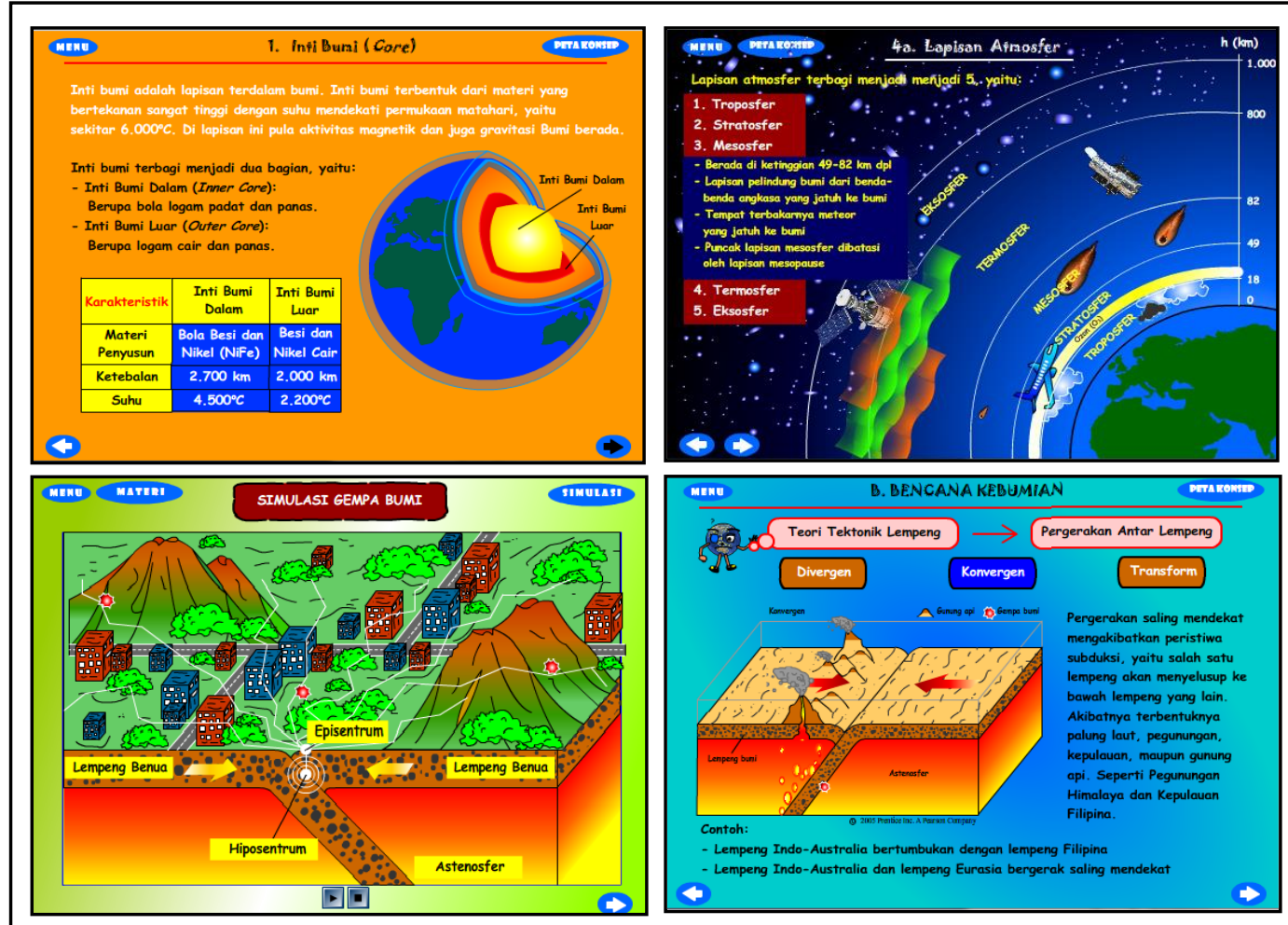

Gambar 2. Contoh tampilan Slide-slide Multimedia Interaktif 


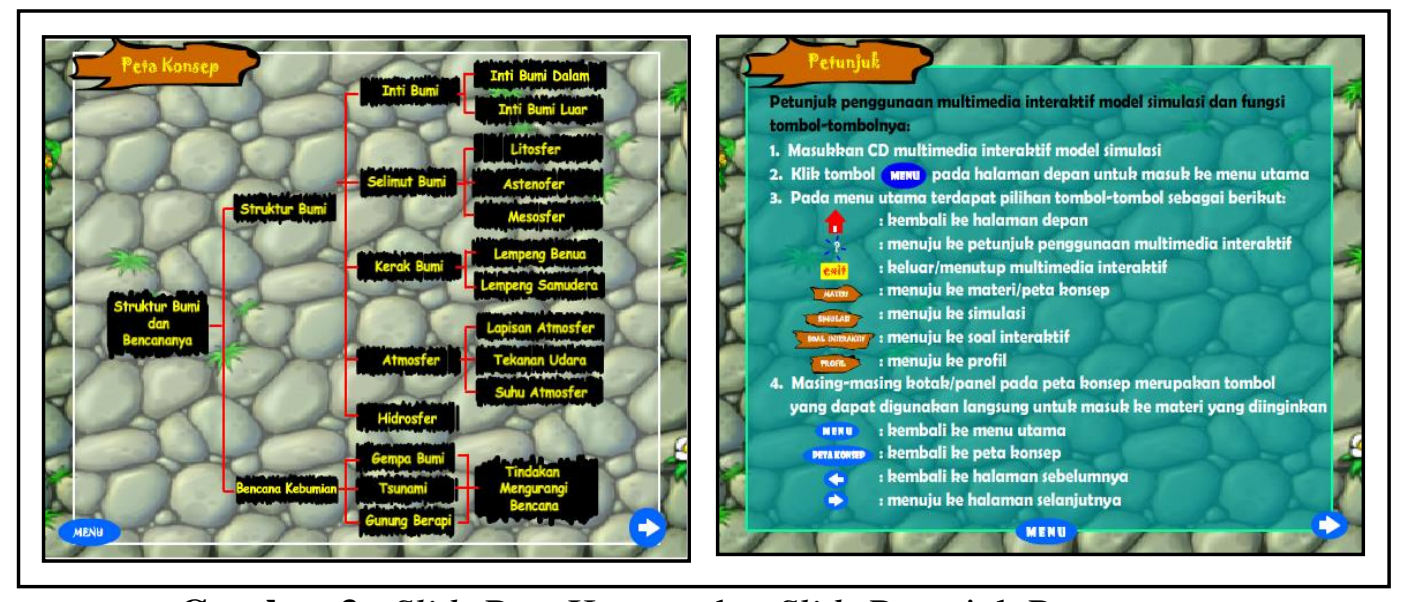

Gambar 3. Slide Peta Konsep dan Slide Petunjuk Penggunaan

Kemanfaatan dari multimedia interaktif model simulasi terletak pada penggunaannya dalam proses belajar mengajar terutama pada materi Struktur Bumi dan Bencananya di kelas VII SMP. Multimedia interaktif model simulasi bermanfaat karena dapat memudahkan siswa memahami materi secara lebih nyata. Menurut Ariani dan Haryanto (2010: 26), penggunaan multimedia interaktif dalam pembelajaran sangat bermanfaat bagi siswa maupun guru, diantaranya: 1) mampu mempermudah siswa mempelajari materi, 2) proses pembelajaran menjadi lebih menarik dan lebih interaktif, 3) jumlah waktu mengajar (ceramah) guru dapat dikurangi, 4) kualitas belajar siswa dapat lebih termotivasi dan terdongkrak, 5) belajar mengajar dapat dilakukan dimana saja dan kapan saja (sangat flesksibel), 6) belajar dapat dilakukan secara klasikal (bersamasama) atau individual, dan 7) sikap dan perhatian belajar siswa dapat ditingkatkan dan dipusatkan.

Keefektifan multimedia interaktif yang dikembangkan diperoleh dari uji keefektifan pada kelompok kecil yang berupa pemberian soal pretest dan posttest kepada siswa. Berdasarkan hasil uji keefektifan diperoleh skor $N$-Gain sebesar 0,7 dengan kategori sedang. Sehingga dapat disimpulkan bahwa multimedia interaktif model simulasi yang telah dikembangkan efektif digunakan dalam pembelajaran karena mampu meningkatkan hasil belajar serta penguasaan konsep siswa. Hal ini diperkuat dengan penelitian sebelumnya yang dilakukan oleh Fitri, dkk. (2014), Oktivina, dkk. (2014), dan Utami, dkk. (2014) yang menyatakan bahwa penggunaan media TIK simulasi sebagai komplemen demonstrasi mampu meningkatkan hasil belajar ranah kognitif siswa, mampu menumbuhkan keterampilan proses sains siswa, mampu membentuk karakter siswa, mampu mengembangkan aktivitas siswa, dan mampu menumbuhkan sikap positif siswa. Gunawan (2016) dalam penelitiannya juga menyatakan bahwa rata-rata penguasaan konsep siswa yang belajar menggunaan multimedia interaktif lebih tinggi dibandingkan dengan rata penguasaan konsep siswa yang belajar tanpa menggunakan multimedia.

Multimedia interaktif model simulasi yang dikembangkan memiliki beberapa kelebihan jika dibandingkan dengan media atau multimedia interaktif yang sudah ada diantaranya, memiliki tampilan yang lebih menarik, mampu menumbuhkan minat dan motivasi belajar siswa, mampu mensimulasikan atau memodelkan 
fenomena kebumian, dibuat praktis dengan tombol-tombol interaktif yang ada, dan dapat digunakan dalam pembelajaran mandiri atau kelompok.

Multimedia interaktif model simulasi yang dikembangkan juga memiliki beberapa kelemahan, diantaranya: hanya teruji dalam lingkup skala kecil (sekolah tempat penelitian) dan belum teruji dalam skala yang lebih besar dan tidak dapat digunakan pada sekolah-sekolah yang tidak dilengkapi dengan fasilitas Laboratorium Komputer dan LCD.

\section{SIMPULAN}

Simpulan penelitian pengembangan ini yaitu: (1) Multimedia interaktif model simulasi yang dihasilkan telah teruji baik dan dinyatakan valid serta layak digunakan dalam pembelajaran. (2) Multimedia interaktif model simulasi materi Struktur Bumi dan Bencananya memiliki kualitas sangat menarik dengan skor 3,58, sangat mudah dengan skor 3,63, dan sangat bermanfaat dengan skor 3,61. (3) Multimedia interaktif model simulasi materi Struktur Bumi dan Bencananya efektif digunakan dalam pembelajaran dengan perolehan skor $\mathrm{N}$ Gain sebesar 0,7 kategori sedang.

\section{DAFTAR RUJUKAN}

Arianai, Niken dan Haryanto Dany. 2010. Pembelajaran Multimedia di Sekolah: Pedoman Pembelajaran Interaktif, Kontruktif, dan Prospektif. Jakarta: Prestasi Pustaka.

Arsyad, Azhar. 2011. Media Pembelajaran. Jakarta: RajaGrafindo Perkasa. Darmawan, Deni. 2012. Teknologi Pembelajaran Edisi Kedua. Bandung: Remaja Rosdakarya.

Fitri, Liza, Suyatna Agus, dan Viyanti. 2014. Pemanfaatan Media TIK
Simulasi sebagai Subtitute

Demonstrasi pada Pembelajaran

Alat Ukur. (Online): Jurnal

Pembelajaran Fisika, 2(2), 65-

76 ,

(http://jurnal.fkip.unila.ac.id/inde x.php/JPF/article/view/4373, 2211-2017).

Gunawan, A. Harjono, dan Imran. 2016. Pengaruh Multimedia Interaktif dan Gaya Belajar Terhadap Penguasaan Konsep Kalor Siswa. (Online): Jurnal Pendidikan Fisika Indonesia, 12(1), 118-125, (https://journal.unnes.ac.id/nju/in dex.php/JPFI/article/view/5018, 18-11-2017)

Mahardika, I Ketut, Afifatur Rofiqoh dan Supeno. 2012. Model Inkuiri Untuk Meningkatkan

Kemampuan Representasi Verbal dan Matematis pada

Pembelajaran Fisika di SMA. Jurnal Pembelajaran Fisika Universitas Jember. 1(2), 165171.

Oktivina, Mawar, Suyatna Agus, dan Viyanti. 2014. Pemanfaatan Media Teknologi, Informasi, dan Komunikasi (TIK) Simulasi sebagai Komplemen

Demonstrasi. (Online): Jurnal Pembelajaran Fisika, 2(1), 123134,

(http://jurnal.fkip.unila.ac.id/inde x.php/JPF/article/view/3726, 2211-2017).

Sukiyasa, Kadek, dan Sukoco. 2013.

Pengaruh Media Animasi

Terhadap Hasil Belajar dan

Motivasi Belajar Siswa Materi

Sistem Kelistrikan. (Online):

Jurnal Pendidikan Vokasi, 3(1), 126-137,

(https://journal.uny.ac.id/index.p hp/jpv/article/view/1588, 10-112017) 
Suyanto, Eko dan Sartinem. 2009.

Pengembangan Contoh Lembar

Kerja Fisika Siswa dengan Latar

Penuntasan Bekal Awal Ajar

Tugas Studi Pustaka dan

Keterampilan Proses Untuk SMA

Negeri 3 Bandarlampung.

Prosiding Seminar Nasional

Pendidikan 2009. Lampung:

Unila.

Tiurma, Lisner, dan Retnawati Heri. 2014. Keefektifan Pembelajaran

Multimedia Materi Tiga Dimensi

Ditinjau dari Prestasi dan Minat

Belajar Matematika di SMA.

(Online): Jurnal Kependidikan, 44(2), 175-187, (http://journal.uny.ac.id/index.php/jk/ar ticle/view/3230, 10-11-2017)

Utami, Purwanti Budi, Suyatna Agus, dan Viyanti. 2014. Pemanfaatan Media TIK Simulasi sebagai Suplemen Demonstrasi pada Pembelajaran Alat Ukur. (Online): Jurnal Pembelajaran Fisika, 2(1), 65-79, (http://jurnal.fkip.unila.ac.id/inde x.php/JPF/article/view/3670, 2211-2017).

Warsita, Bambang. 2008. Teknologi Pembelajaran (Landasan dan Aplikasinya). Jakarta: Rhineka Cipta. 